\title{
In Search of a New Theatre for Children
}

\author{
Ewa Tomaszewska \\ University of Silesia, Poland \\ E-mail address: tomaszewska.ewa61@gmail.com
}

ARTICLE INFO

\section{Keywords:}

Theatre for children

Art

Education

Dorman Jan

\section{Article history:}

Received 1 October 2013

Received in revised form 19 March 2014

Accepted 7 May 2014

ISSN:

DOI: 10.15290/ctra.2014.01.01.10

\section{A B S TRACT}

The digital revolution affects every aspect of our lives, changing them very quickly and efficiently. This process also concerns our fundamental values, which take on an ambivalent character (good-charity, truth-manipulation, beauty-ugliness or love-sex). This is a new challenge for art and education and for theatre for children, seen as a form of nonformal education.

Modern society has forged a deep chasm between childhood and adulthood (Van den Berg, 1988) which continues to grow. ${ }^{1}$ From the very beginning, art for children has been created by adult artists, ${ }^{2}$ from their life-perspective and experiences. How can these artists communicate with a new, young audience if their languages and their ways of per-

\footnotetext{
${ }^{1}$ Today a difference resulting from a different attitude to digital reality is coming to the fore. Marc Prensky expresses this difference in terms of digital skills: Digital Natives - young people who are all "native speakers" of the digital language of computers, video games and the Internet; Digital Immigrants - older people who have grown up without digital technology, who need to learn to adapt to their new environment (2001). ${ }^{2}$ This is another kind of theatrical expression that I could call "children's theatre". The difference between these two forms is great and noticeable. Generally, the former is oriented towards creation and its product, the latter also towards creation, but more in an educational sense; the first is directed to the audience, the second - to itself. Certainly both are linked and mutually interact.)
} 
ceiving reality are so different? At the same time, school as a place of education is beginning to lose its significance in favour of non-formal education, which is situated outside school and is conducted after school at different levels and places, which are not always safe. This is a spacious area where art for children - in particular theatre for children plays an important role. The most important thing is to seek a new language to communicate with a new, young audience. The second challenge is to make the form of the artistic process interactive. The use of a variety of means is a standard form of contemporary communication and it provides more possibilities for affecting the audience and stimulating their intellectual and emotional activity. The third issue is connected with the inclusion of teachers and other educators in the artistic process of the creation of performances for children. Their help could enable the spheres of artistic influence to be enlarged. Certainly, the theatre is not an educational institution. It is an institution of art. But the theatre has had an educational function since antiquity. This is the first point: the second is necessity. If theatre artists want to have an audience in the future, they will have to prepare young people for the reception of this art and encourage them to regularly participate in this kind of art.

For over 10 years I have been running activities with students in "social and cultural animation"3 which is characterized by artistic experiments. The basic aim is to search for a new form of theatre performances, which will be attractive to contemporary audiences and at the same time, communicate important messages. The second challenge is the search for a theatrical language that will be both appropriate to the potential of children's audiences and relevant to their experiences as formed by media and digital reality. The students and I search for a means of artistic communication which will appeal to the audience's emotions and imagination. This involves stimulating them to create their own sequences of associations and create free references to their own lives. Our inspiration was the theatrical concept and ideas of Jan Dorman, ${ }^{4}$ put forward and partly carried out by him in the 1960s and 70s (Dorman, 1981).

\section{DUCK AND HAMLET (2003) ${ }^{5}$}

The performance was aimed at children aged 5-6 and carried out according to Jan Dorman's scenario. Two theatrical props: big ducks on wheels - a blue and a yellow one, were brought to two preschools by actors. For the children they were props from another

\footnotetext{
${ }^{3}$ The specialism "social and cultural animation" is offered on the M.Ed. degree course at the University of Silesia, Faculty of Ethnology and Educational Studies in Cieszyn.

${ }^{4}$ Jan Dorman - one of the greatest Polish artists who created the new mainstream of theatre based on children's games and plays; he also established Teatr Dzieci Zagłębia in Będzin (near Katowice, the capital of Polish Silesia) where he formed an original idea of theatrical and aesthetical education for children.

${ }^{5} 57$ children from two preschools (experimental group) and 60 children from three preschools (control group) took part in the project. The children's reactions were recorded. One or two days after the performance conversations were conducted with the children on the basis of previously prepared questionnaires.
} 
world, a little mysterious and strange, but really interesting. The ducks stayed there for 2 weeks. During this time the children greeted the ducks spontaneously, played with them, and told them some personal stories, often as whispered secrets. Finally, on the fifteenth day of their stay, the ducks disappeared. The same day, the children went to the theatre, where they found their ducks on stage, as part of a play (Tomaszewska, 2004).

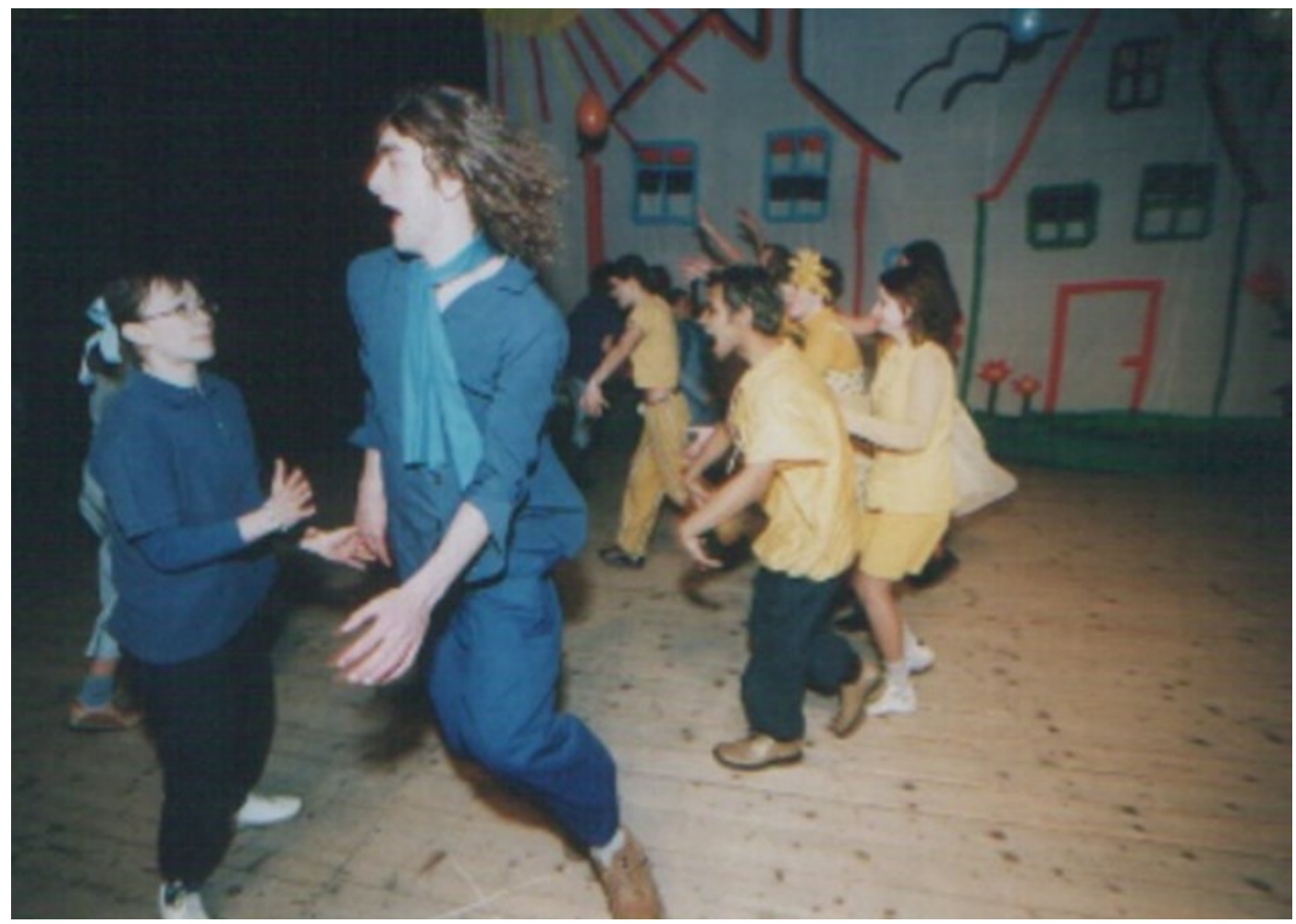

FIGURE 1 Duck and Hamlet (2003).

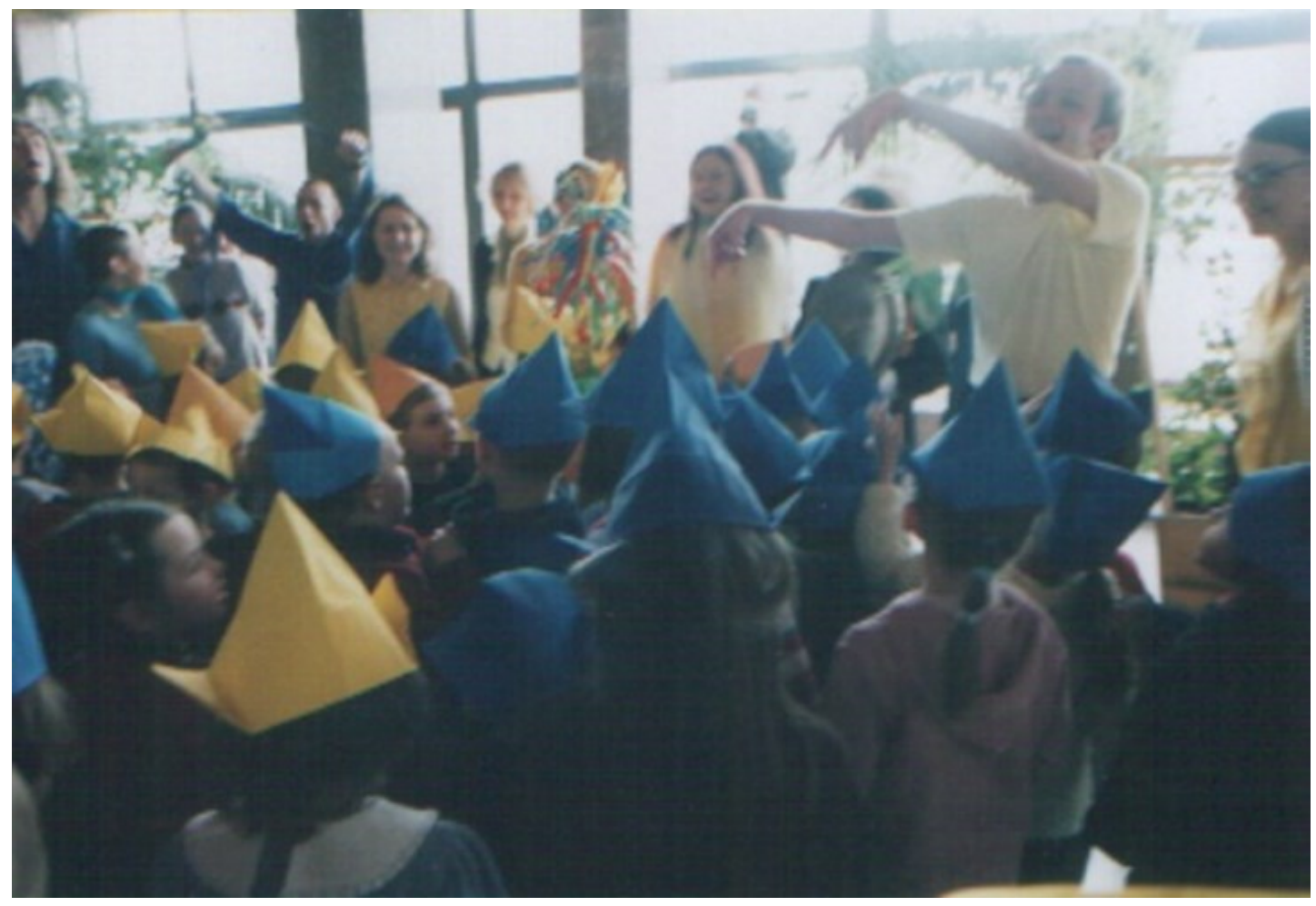

FIGURE 2 Duck and Hamlet (2003). 
The play wasn't easy: completely without a story, based on the relationships between characters, with a free structure. The action was not driven by logical situations, but by associations. The framework of the show was a rhythmisation inspired by children's counting games, children's play, and folk traditions. According to Dorman, they were treated as conventions which are familiar and recognizable to children - even if not always and not completely comprehensible. The movement on stage was strictly conventionalized. The play was built on ritual gestures, processions, dances, and mechanical or spontaneous movement. The same applied to the way the actors interpreted their lines. They spoke rhythmically, the lack of interpretation removing the meaning from their words, they spoke in one breath, they whispered, they sang, they spoke with exaggerated interpretation or ecstatically, they spoke chorally. It ought to be stressed, however, that all the theatrical action was inspired by the children's games which accompanied the Ducks' stay in the preschool. The performance progressed quickly; each game constantly transforming into other games, but the children reacted wonderfully; no bored reactions were observed, and after the performance they were able to describe quite competently what had happened on stage.

A scene which evoked very strong emotions for the audience was the moment when the characters dressed up their ducks for a competition. The prize in the competition was a big drum. The chief of the blue group stole the yellow duck's props. The children were really disgusted and screamed: "Look out! A robber!" The situation was serious - the actors were not able to continue the play. This reaction was really bizarre, because it was not usual for the children to behave in a similar manner when playing with each other. But in the theatre they showed their disapproval of this behavior. After the show the children said that, because of the performance they had learned to be good and honest: "This is what the ducks told me". After this event the blue group was lost - each of their entrances was accompanied by the exclamation: "Robbers! Watch out! It's a trap!" The same scene was also watched by children from a preschool, where we had not carried out the first part of the experiment. The reaction of the audience was different - the tension was expressed by silence. The children seemed repressed, unforthcoming, no spontaneous reactions could be seen, their emotions were expressed more stereotypically, simply by applause.

Finally, the yellow group reclaimed their props and the children were satisfied. We asked the children after the experiment: "What has the Duck changed in your life?" The children answered: "Everything! I'll look at ducks in a new, different way"; "I'll be nicer to them"; "I don't know, but I miss them very much"; "I love ducks!"; "I go to the pond and I look at ducks. Before I didn't go because there was nothing to look at"; "I like ducks 
more then I used to"; "The duck has replaced the Pink Panther and Harry Potter because I liked both the ducks so much"; "The play was happy, but it's sad in my home".

As you can see, the children's theatrical experience had been transformed into reality. It also confirmed that the children who had met the Ducks earlier, experienced the performance more intensively and understood the meanings of the theatrical situations much better. They were more open and confident than the other children. This can lead to the supposition that traces remained in their memories which would form a horizon of associations for the future.

\section{THE PONY (2006-2007) 6}

The idea of the horizon of associations was tested in the second project - The Pony which was also addressed to five- and six-year-old children (Tomaszewska, 2007). We began at the preparatory phase, which was carried out in two different ways. One group of children had to go to the theatre 3 times to watch three short shows (2'5") about the Pony as three successive theatrical images, which described the main character of the performance they would later see. The other group of children met the Pony during four short meetings organized at their preschool. The first situation was particularly bizarre and irritating for the children - they had to make more effort to go to the theatre than to actually watch the shows. But we had been hoping this would stimulate their imagination and the performance would last from the first meeting until the end of the performance in the theatre. In the second situation we did not stimulate the children's imaginations through theatrical convention, but through play.

The actors visited the preschool with 4 short, 5-minute paratheatrical presentations. Here again, the aim was to introduce to the everyday preschool routine an element of another world - the world of theatre, and also to create a surprising and thought-provoking situation. First there appeared a fairy, who conjured up a little pony, then Pierrot pulling a wooden pony on a cart, then a group of actors with a rocking horse, which was used as a vehicle to enter the dream world. During the last meeting, a package containing 4 sticks and a board was opened. The actors built a bench from these elements with the children and asked them to imagine it was a horse, to mount it and set off on a journey to the world of the imagination. This element of the experiment turned out to be the most difficult. The children found it hard to accept the convention, and when they finally joined in with the game, their journeys turned out to be quite mundane - they travelled to various cities and countries (e.g. to Łódź in Poland, or Ireland). Only sporadically did elements of a fantastic journey appear.

\footnotetext{
${ }^{6}$ We worked with 7 preschools, including 5 in the experimental group (91 children) and 2 preschools in the control group (41 children); we repeated the entire project twice.
} 


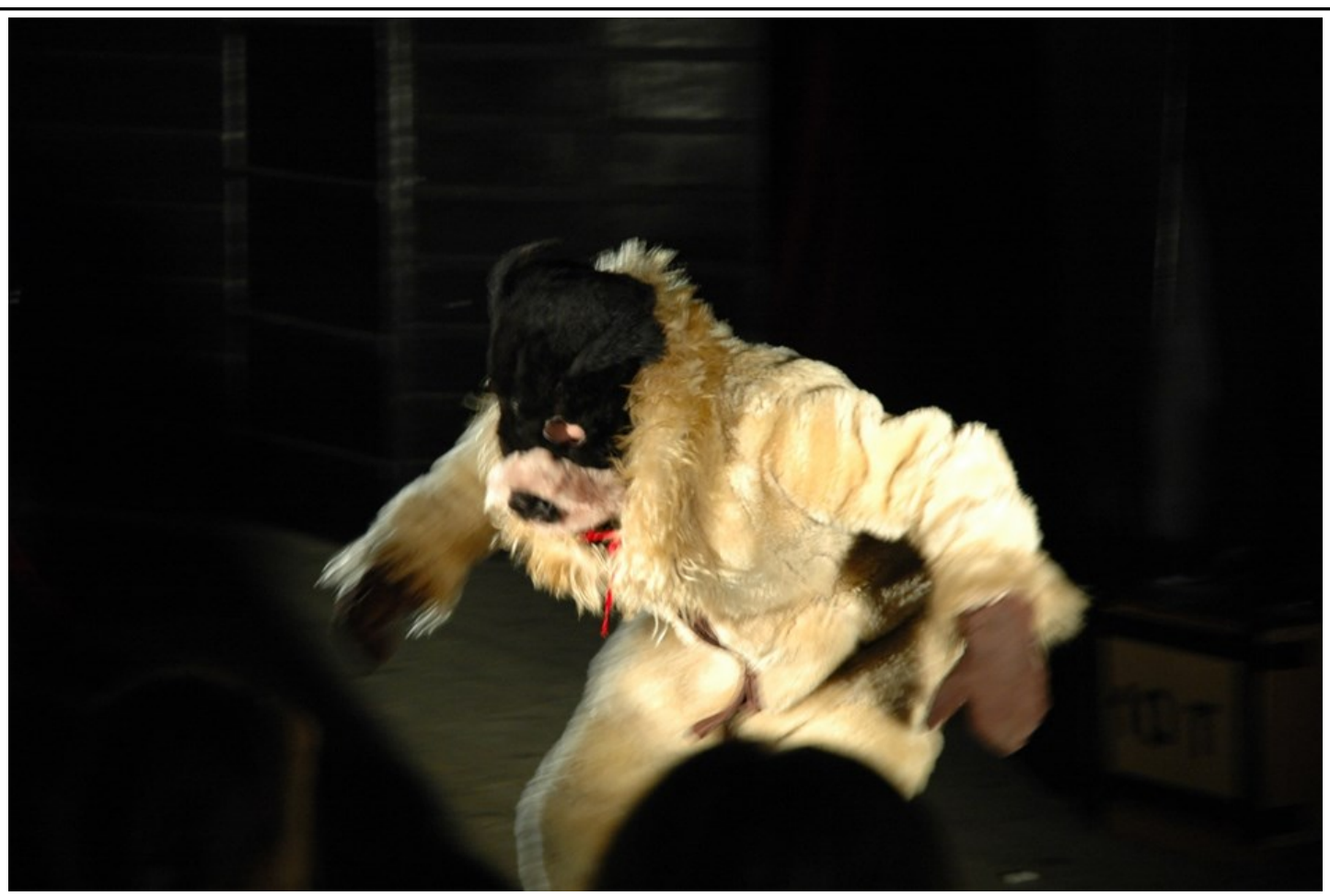

FIGURE 3 The Pony (2006-2007).

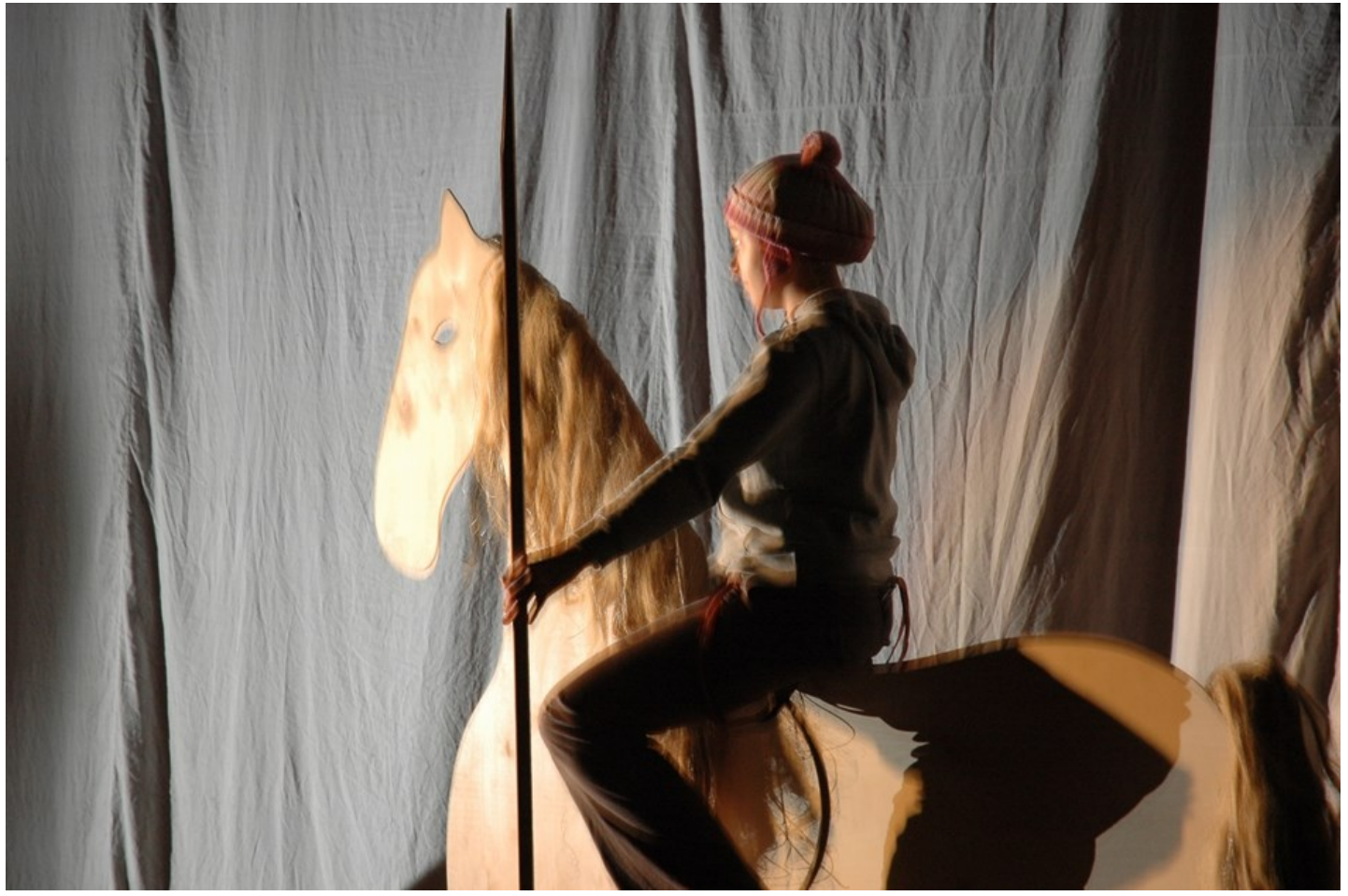

FIGURE 4 The Pony (2006-2007).

Following the first part of our project, which lasted from 8 to 10 days, the children went to the theatre for a performance. The theatrical action was set at the circus. There appeared different characters borrowed from masterpieces of world literature or from folk customs. Each one had a symbolic meaning, e.g. Mother Courage from Brecht was the symbol of an anguished, suffering mother, Cyrano de Bergerac - an independent artist, Candide an absurd philosophy of optimism, Pierrot and Colombine from Alexander Blok were icons of unhappy love etc. The Bear comes from old rituals of passage and represents 
the uncontrollable and mysterious power of fertility, so it serves a double meaning: the power of life, but also slavery and rape. The children understood this double meaning very well and after the performance they said: "The Bear was scary, as well as nice"; “The Bear was horrible but I wasn't scared of him because he had nice fur”.

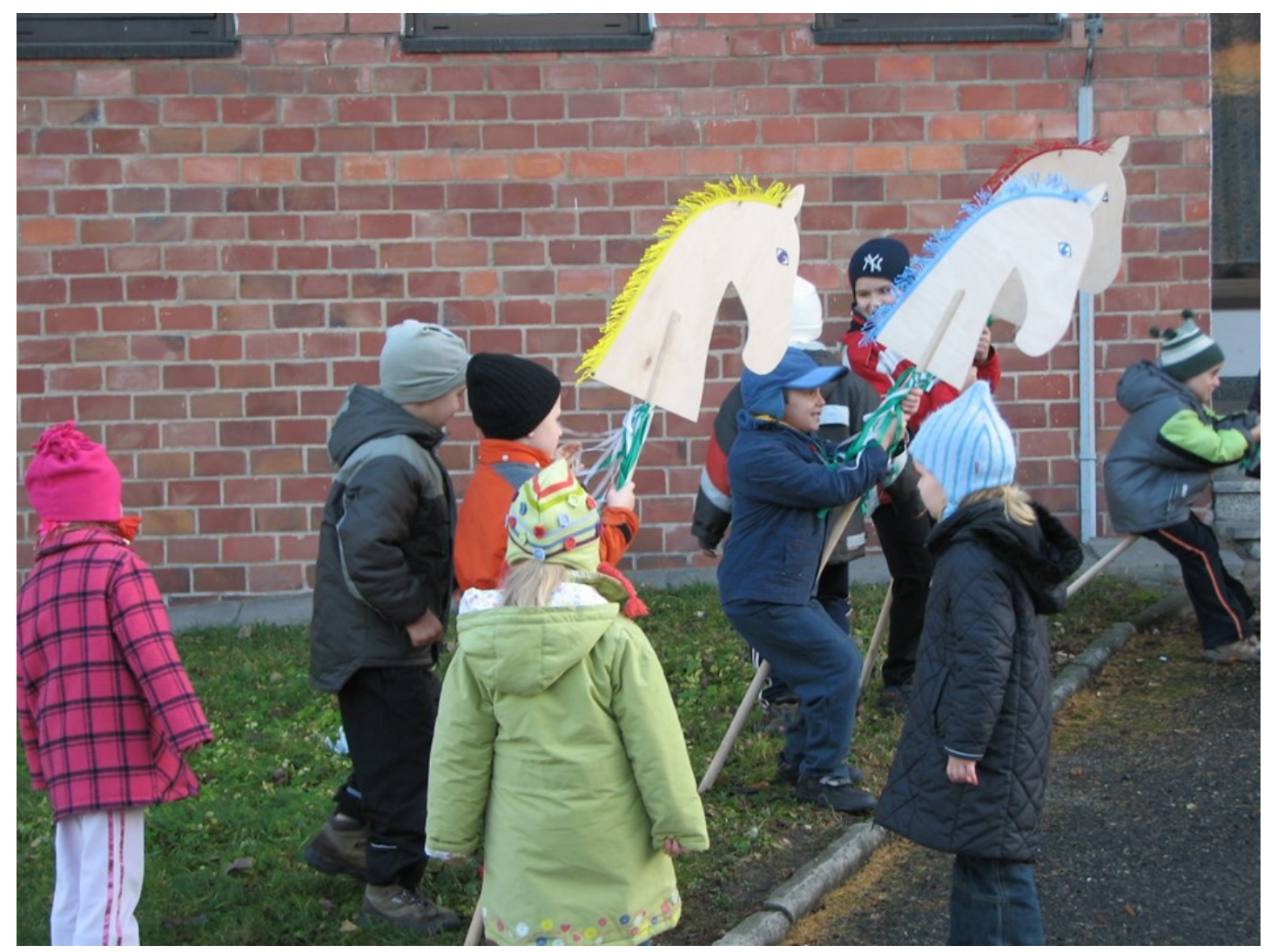

FIGURE 5 The Pony (2006-2007).

The other character from Polish folk tradition was the Devil. In our play he comes from Marlow's play: The Tragical History of the Life and Death of Doctor Faustus, which meant that he was a tragic character. In our performance we connected the Devil with the folk tradition in which this character is usually represented. There was the Mother, who liberates, purifies and saves both the Faust-Devil and the Bear by removing their masks. In our performance, the audience could also see two girls - one happy, one sad - representing two sides of the same nature. Stella ${ }^{7}$ was an icon of joyfulness, optimism and youthful faith in the future and the Little Match Girl from Andersen was the symbol of an unhappy childhood. They both wake the Bear up. The child with its little Pony on wheels symbolizes every child who has an imagination and dreams. During the performance, the Pony becomes a big horse - the vehicle of our dreams. Finally the child mounts the big horse and becomes Don Quixote. The performance's meaning was focused around this character. It talked about not giving up one's dreams, because only in our dreams are we truly free. It appeared that in spite of all the formal and semantic difficulties the children interpreted the actors' intentions correctly.

\footnotetext{
${ }^{7}$ From the poem The Coffee Mill (Młynek do kawy) by K. I. Gałczyński.
} 
Of course, little children could not know these characters and all the meanings described. But I believe this theatrical experience will leave traces in their memory, which will be filled by this content in the future, when the children come into contact with great examples of our culture's art. This action is directed towards the future and this horizon of associations would be something to refer to. In the future, when children come across a character like Don Quixote, they will perhaps remember something from their childhood ("I've seen this somewhere") and this will be helpful in their education. Jan Dorman (1968, p.47). wrote: “...I am not afraid to put on incomprehensible plays, composed only of images and associations. It is my principle that theatre ought never to explain, but merely to suggest. Theatre exists to make people more sensitive! I do not allow the audience to watch the play passively but I force them to be constantly vigilant, to be active, to think."

This is why our theatrical interactions were also connected with the enlargement of theatrical space extending beyond the boundaries of the stage, into the aisles and even out of the theatre itself. After the performance, on the way to the cloakroom, the children came across various ponies: rocking horses and hobby horses. The children stopped by them, played and talked with them.

Later conversations revealed that the children who had watched the performance without previous preparation experienced it in terms of sensations, but also quite superficially. The performance opened their imaginations to various associations, but not necessarily connected with the performance itself. In the case of the remaining children, having been earlier introduced to the subject influenced the orientation of the associations and the connection with the performance's meaning. They also demonstrated that they had enjoyed the performance. To the question: "Would you like to see the performance again?" the children answered: "...l'd like to very much, I could watch it a hundred times, it was awesome there; I felt great; I was happy; I felt warm in my heart; it was fun at first, then someone took us downstairs, they told us to put on our coats and took us back to preschool".

\section{THE COFFEE MILL (2005)}

The third project was aimed at older children, in the 11-14 age group. ${ }^{8}$ This group of viewers is the most problematic - but also challenging - because they are between childhood and adolescence. They often rebel against adults and all forms of restriction, they mistrust everybody and are very often confused and lost in the abundance of possibilities, requirements and emotions. This is the effect of the difficult period of puberty and

\footnotetext{
${ }^{8}$ Children from grade 6 of elementary school and from grades 1 and 2 of junior high school (86 children in total) took part in the experiment.
} 
a search for one's own way. But it is very important to create performances for this audience in order to give them ideas, guidance and some indicators.

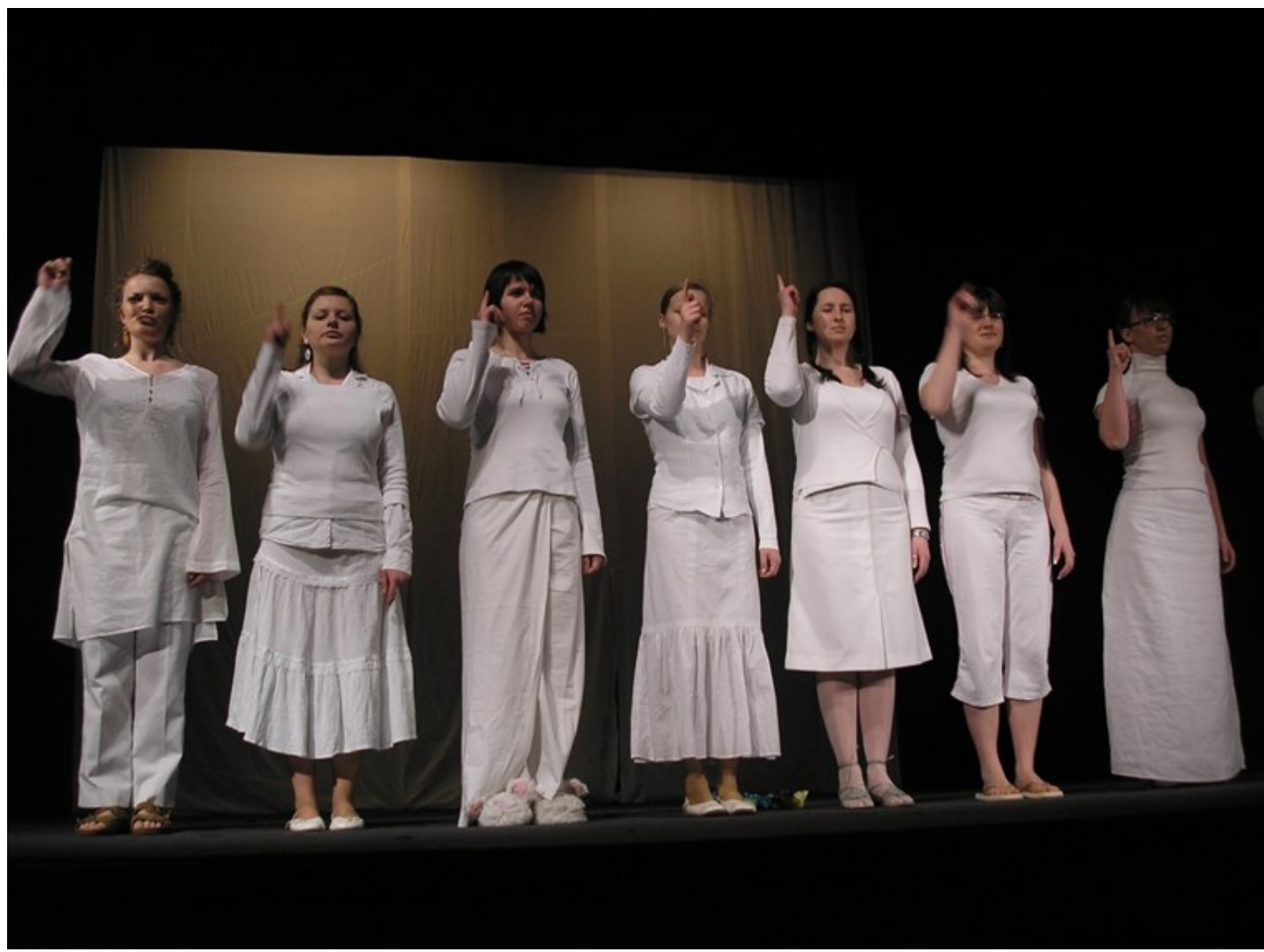

FIGURE 6 The Coffee Mill (2005).

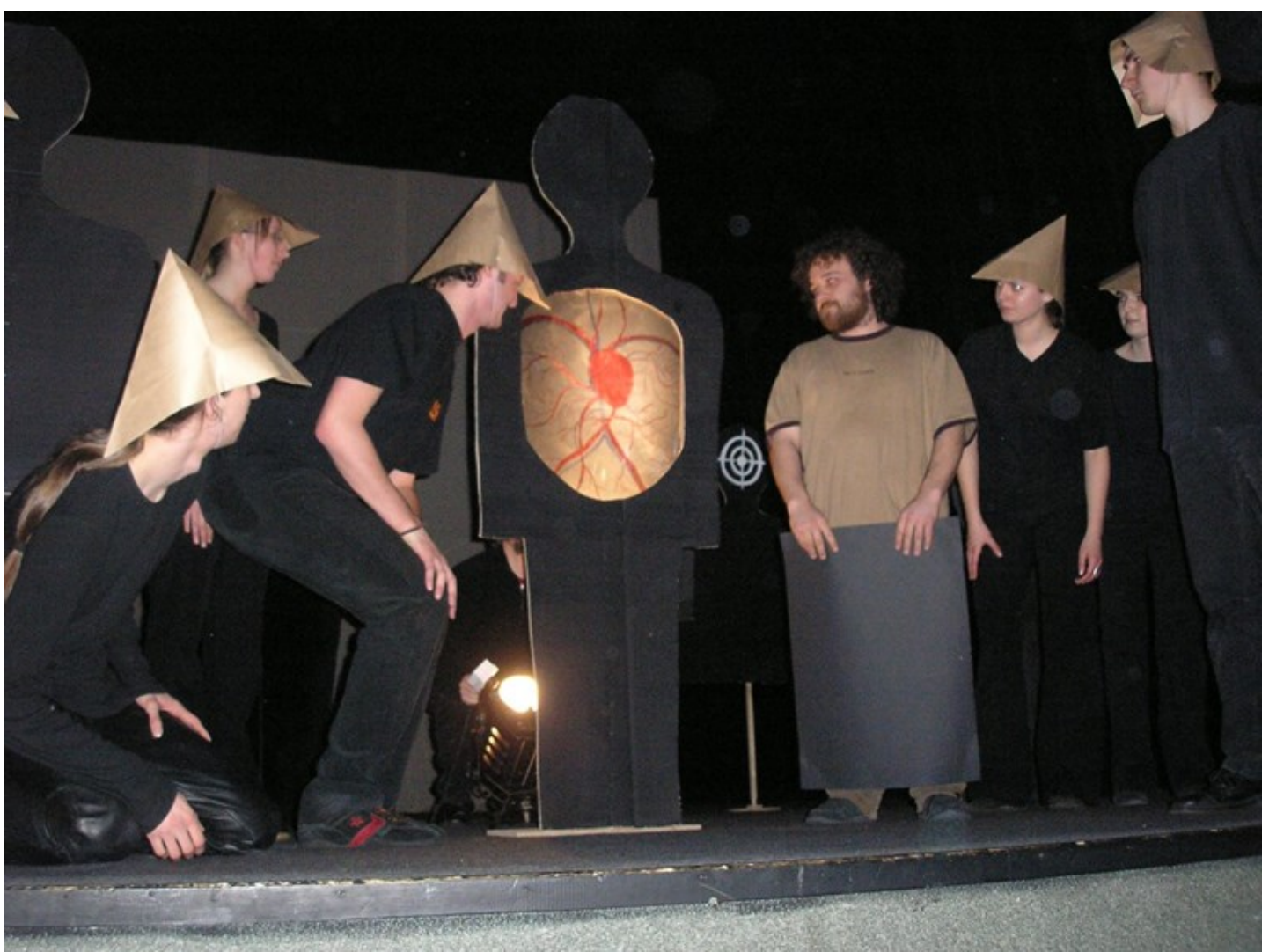

FIGURE 7 The Coffee Mill (2005). 
The literary inspiration was a short story by the Polish poet K. I. Gałczyński. The performance consisted of several complementary elements: a poster, arrangement of the theatrical aisle, a theatrical programme and the show itself. The main character of this play was an object - a coffee mill which had been given as a wedding present to a railway man, Mikołaj, and his wife Celina. For many years it was used to grind coffee. But finally it broke down and became useless. Because "it didn't want to die on a scrap heap" it escaped and had a lot of adventures. A guardian angel guided the Coffee Mill through the dangers of life. The audience could reproduce this story from many different theatrical scenes (Tomaszewska, 2006).

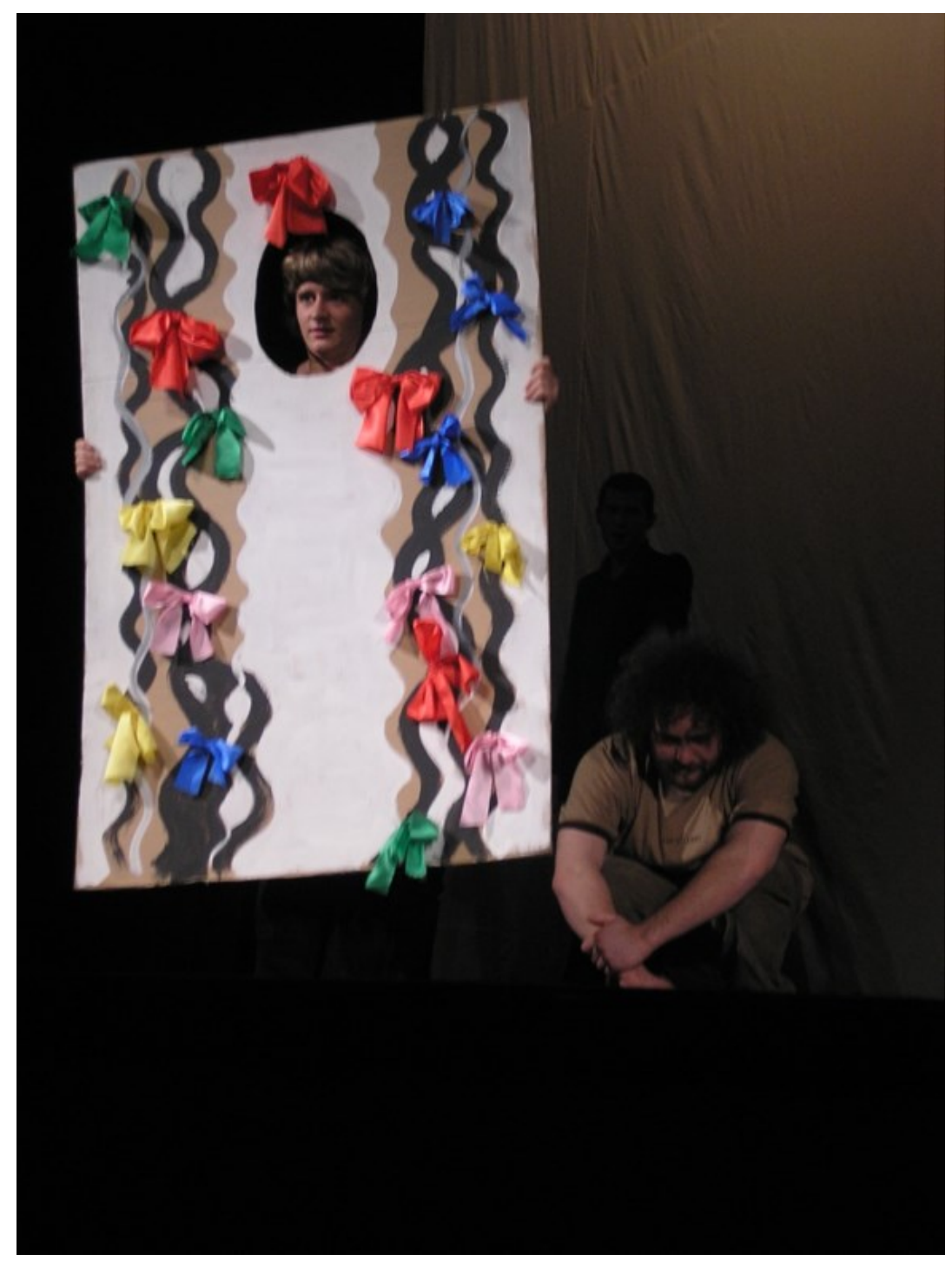

FIGURE 8 The Coffee Mill (2005).

This character emerges from the interaction between the form of the object on the poster and the image created by the live actor on the stage. In our play there was no information about Mikołaj's profession, but before the performance the young audience could see an exhibition about trains in the aisle which was complementary to the stage character. In the theatrical programmes, which were made in five different versions (each 
one in a different colour), the children could read fragments of Gałczyński's poem which never appeared in the show. We hoped that the short texts would give fuller meaning to the performance and the programmes' various colours would mean that the audience would notice the differences between the quotations and would read more than one passage out of curiosity. It turned out that the children wanted to have a programme of the same colour as their friends beside them. Uniformity, being like everyone else, identification with the group, and not curiosity, turned out to be the dominant motivation. Apart from that, the children simply did not read the programme, and even if they did, they only read the quotation they were given: $51 \%$ of the audience stated that they had read the programme, but only a little over half of them (around 30\%) were able to say what it was about, and only 21 children (24\%) could link the text to the performance's content.

In the piece we used the same theatrical means as in earlier performances, for example rhythmization appearing in all the layers of performance and the action was based on associations. The characters were internally dualistic and consisted of actors and props who complemented each other. We used a chorus as in ancient Greek theatre. The speech uttered on stage was treated like music: joining, mixing and interpenetrating sounds.

The scene where the Coffee Mill is sent to a hostel for lost things made a big impression on the young people. After the performance, the children referred to this place as: an orphanage, a home for old people, a residential care home, etc. The audience understood very well that the Coffee Mill was not really an object, but a metaphor for any abandoned or lonely human being.

Another scene showed that you should not count on help from anyone else and that it is difficult to find consensus. Stella, Mikołaj's granddaughter, a symbol of good faith and optimism, tried to find the abandoned Coffee Mill, but it was difficult, because nobody wanted to help her, nobody listened to her; people only thought about themselves.

War was constantly being waged on the island of Atra. The Coffee Mill showed a general and his army that a soldier "has a heart and that ordinary human blood flows inside each soldier's veins". The audience was laughing, but it suddenly went silent - it was proof that the young people had understood our pacifist meaning.

Finally, the Coffee Mill was reunited with his family, and this optimistic meaning proved the most important for the young audience. $75.5 \%$ of the audience stated that the performance ended happily: “...because the Coffee Mill returns home; ...because they found the Coffee Mill and didn't want to throw it away any longer; ...because the Coffee Mill has a family again and everyone loves him". There were also statements expressing mistrust towards adults: "The Coffee Mill might be deceived by its owners again". The majority of 
the audience identified with the protagonist. This was particularly apparent in the art work which was done after the performance. It showed that the children felt lonely and rejected.

Creative audience participation in the play does not depend, of course, on placing children in the drama, but on drawing the audience into co-creating the action by engaging their intellectual faculties and sensitivity, on activating the children's imagination and on the interactive nature of this process. In this way I think we came close to a theatre of community. ${ }^{9}$

Our performance provoked the audience to reflect and triggered their imaginations, which they admitted themselves by saying: "the performance made me think". As in the previous projects, the audience related their thoughts to their own lives. They said after the play: "When somebody is ill or old you can't send them to hospital, but you have to take care of them"; "Sometimes people want to have a dog, but after some time they get bored and throw it out. Or they take in an orphan, but then they get bored and stop looking after her. But the child feels that and is alone and unhappy, like that Coffee Mill".

These three experiments show the possibilities for forming a new programme of theatrical education, which can be created for all age groups of children. Additionally, this theatre must be flexible, because children change quickly and develop, and as a result, their needs change too. This kind of theatre should be modern, creative and fun. This new form of theatre could be based on children's counting games and forms of play, on metaphor and symbol, on traditional and even ritual theatre. These forms, treated as theatrical language instead of words, could be the link between an audience of children and the adult creators. And finally, theatrical creators - stage directors, actors, stenographers and composers - should have something to tell the young audience. I observe performances aimed at children which are empty or full of infantile content, without an important message. Very often creators play and experiment with values, treating traditional stories as a springboard for their strange or questionable artistic concepts. We should remember that art, in particular theatre, should help children in their individual development, as well as preparing new theatrical audiences for the future. This is very important in our world, which is making human beings increasingly homogenous and cybernetic. It is necessary to collaborate with institutions of education and simply with teachers. Otherwise, they may not understand our artistic and pedagogic issues and aims and thus detract from them. I hope that my theatrical attempts show that this collaboration is possible and may even reinforce artistic stimulation.

\footnotetext{
${ }^{9}$ In the book The Second Reform of the Theatre Kazimierz Braun describes the phenomenon of the theatre of community in the following way: "A theatrical play would be an enduring social process of reciprocal communion. A process of joint creation (...) It is an extreme but logical consequence relying on the understanding of theatre as an artistic process in time and as a social phenomenon. It is clear that theatre understood in these terms at last breaks away completely from the idea of a play performed by actors for the audience. It concerns theatre created together. Not for, but with, together" (1979:144).
} 


\section{REFERENCES}

Carr, N., Is Google Making Us Stupid? What the Internet is doing to our brains, Atlantic Magazine, July/August 2008.

Berg Van Den, J. H. (1988). Dziecko stało się dzieckiem [The Child Became a Child]. In M. Janion \& St. Chwin (Eds.), Dzieci [Children], 2 (pp. 226-254). Gdańsk: Wydawnictwo Morskie.

Braun, K. (1979). Druga reforma teatru [The Second Reform of the Theatre], Wrocław: Ossolineum.

Dorman, J. (1968). Mój teatr [My Theatre], Teatr Lalek, 1-2, 46-48.

Dorman, J. (1981). Zabawa dzieci w teatr [Children Playing at Theatre]. Warsaw: COK. Prensky, M. (2001) Digital Natives, Digital Immigrants, 2001. On the Horizon, MCB University Press, 9, 5 according to: http://www.innovateonline.infolindex.phpview=article \&id=705 (accessed: October, 2009). The article is reprinted here with permission of the publisher. The Fischler School of Education and Human Services at Nova Southeastern University.

Richrads, G. Wilson, J. (2004) The Gglobal Nomad. Backpacker Travel in Theory and Practice, Channel View Publications, ; http://books.google.pl/

Tomaszewska, E. (2004). Kaczka i Hamlet. Eksperyment teatralno-pedagogiczny [Duck and Hamlet. A theatrical and pedagogical experiment]. In K. Knapik \& W. A. Sacher (Eds.), Sztuka w edukacji i terapii [Arts in Education and Therapy] (pp. 82-95). Krakow: Uniwersytet Śląski Wydział Pedagogiki i Psychologii Zakład Arteterapii, Impuls.

Tomaszewska, E. (2004). Kaczka i Hamlet. Kilka uwag z eksperymentu [Duck and Hamlet. Some comments from the experiment]. In K. Krasoń \& B. Mazepa-Domagała (Eds.), Ekspresja twórcza dziecka [The Creative Expression of Children] (pp. 231-238). Katowice: Górnośląska Wyższa Szkoła Pedagogiczna im. Kardynała Augusta Hlonda, Librus.

Tomaszewska, E. (2006). Młynek do kawy, czyli teatr dla dzieci starszych [The Coffee Mill or Theatre for Older Children]. In K. Krasoń \& B. Mazepa-Domagała (Eds.), W kręgu sztuki i ekspresji dziecka. Rozważania inspirujące [In the Circle of Art and Expression of the Child. Inspiring Considerations] (pp. 238 - 244). Katowice-Mysłowice: Centrum Ekspresji Dziecięcej przy Bibliotece Śląskiej, Górnośląska Wyższa Szkoła Pedagogiczna im. Kardynała Augusta Hlonda w Mysłowicach. 
Tomaszewska, E. (2007). Tworzenie horyzontu skojarzeń. Eksperyment teatralnopedagogiczny „Konik” adresowany do dzieci młodszych [Creating a Horizon of Associations. A theatrical and pedagogical experiment "The Pony" aimed at younger children]. In Krasoń K. \& Mazepa-Domagała B. (Eds.) Oblicza sztuki dziecka. W poszukiwaniu istoty ekspresji [The Faces of children's art. In search of the essence of expression] (pp. 254-264). Katowice-Mysłowice: Centrum Ekspresji Dziecięcej przy Bibliotece Śląskiej, Górnośląska Wyższa Szkoła Pedagogiczna im. Kardynała Augusta Hlonda w Mysłowicach.

Corresponding author at: Ewa Tomaszewska, Faculty of Ethnology and Educational Science, University of Silesia in Katowice, 62 Bielska St., 43-400 Cieszyn, Poland. E-mail: tomaszewska.ewa61@gmail.com 